\title{
LOCAL DEVELOPMENT THROUGH SELF-HELP: SOME TUNISIAN CASE STUDIES
}

\author{
Bassem NEIFAR \\ UMR TELEMME \\ Aix-Marseille University and CNRS France, \\ Syfacte Laboratory, \\ Rue des Noisetiers 1, 44600 Saint-Nazaire, France \\ neifarb@yahoo.com
}

\begin{abstract}
Through revolting on the 14 of January 2011, Tunisians showed their rejection of the political, economic and social system. In fact, the political system was locked since their independence in 1956 and especially during the presidency of Zine El Abidine Ben Ali (1987-2011). Nevertheless, some local development systems or local populations used their entrepreneurship and have established an "anti-system" which marks their response to the system imposed by the State. Therefore, in this paper we have chosen to consider two cases of local development through self-help. The first case concerns agriculture and will be illustrated by Ghannouch, north of the town of Gabes. The second case will concern fishing and will be demonstrated in the Kerkennah islands in the Mediterranean Sea, in front of the city of Sfax. The Ghannouchis faced the narrowness of their agricultural land, and the Kerkennians faced the narrowness of their marine horizon. The Ghannouchis intensified their agriculture through jumping and land reclamation to gain new areas away from their essential space. Nevertheless, the Kerkennians remained closely linked to fishing with considerable efforts to pursue fishing campaigns in the Gulf of Gabes and away from their seas. These results are verified by field surveys and confirmed by diachronic images from Google Earth.
\end{abstract}

Key-words: Gulf of Gabes, self-development, land reclamation, mobility, fishing campaigns, Tunisian revolution, Google Earth.

\section{Imbalances between regions and development failure}

For many observers, the Tunisian revolution seemed to be unexpected and unpredictable. Yet, the first rebellion against the regime of Zine El Abidine Ben Ali, denouncing youth unemployment and lack of development, began in 2008, in the region of Gafsa (South-West). The crisis in the inland areas and rural areas was among the elements that triggered the revolution. A flashback on the development policies in the country since the country's independence in 1956 shows that the West Centre has suffered more than the other regions (Fig. 1). It has also benefited less from the dynamics experienced by the rest of the country. It is certain that the western parts of the country continued to suffer after the country regained its independence, particularly the West Centre which is the birthplace of the Tunisian revolution. However, the coast, where the largest private 
and public investments concentrated in the country, has also experienced an imbalance between urban and rural areas. Before January 14 the response of different marginalized areas in the coastal or inland area to the crisis of the system differed from one region to another. Some people, in their spaces, chose self-development in industry, agriculture, and services. Others, in their localities, were more fatalistic and shut themselves away while waiting for changes coming from the outside. Nevertheless, they all protested on January 2011 to go against the regime.

While field surveys and social studies continue to be used to analyse different people's reactions from marginalized areas to cope with the inevitable, the geographers produce and analyse maps of these areas, interpret field studies, and find many arguments to explain the dynamics of people in connection with their spaces. Nowadays, changes and new arguments come with the Internet and with Google Earth ${ }^{1}$. Google Earth offers the facility of geographical measurements. It also offers the verification of some actions on the ground by reviewing and comparing satellite images from different periods. We will experiment with this tool for approving our fieldwork and to increase its scientific dimension.

This article seeks to understand:

- How regional communities in Tunisia which suffer from a difficult and hostile environment and lack of support from the State or regional authorities (example of Kerkennah Islands and the city of Ghannouch) are often forced to develop their own development strategies?

\section{Failure of planning policies}

\section{An inherited planning crisis}

Since the early years after the country regained its independence there has been a development policy aimed at reducing the former colonial imbalance between the North and the South, especially between Tunis and other regions, but also between the coast and the interior.

The national planning policy has been marked by three phases (Daoud 2011):

- The first, with the report of Eight (D.A.T. Groupe Huit), is considered the first master plan of the country, entitled 'Cities and Development', and was presented in 1973 and covered the period 1956-1985. This master plan aimed to make a planning policy and affirmation of the nation-state.

- The second, considered the first official National Land-use Planning Strategy (SNAT) for the period 1985-1996, was aimed at improving the regional balance (DGAT 1985).

- The third (SDAT), 1996-2011 (Fig. 2), aimed for metropolisation and coastal development, and involved increasing the weight of the coast at the expense of the inner regions which were the cradle of the revolution. This plan considered that inland areas were fragile and required protection against overpopulation (Dirasset-Groupe Huit-IGIP, 1997).

\footnotetext{
1 Since version 5.
} 


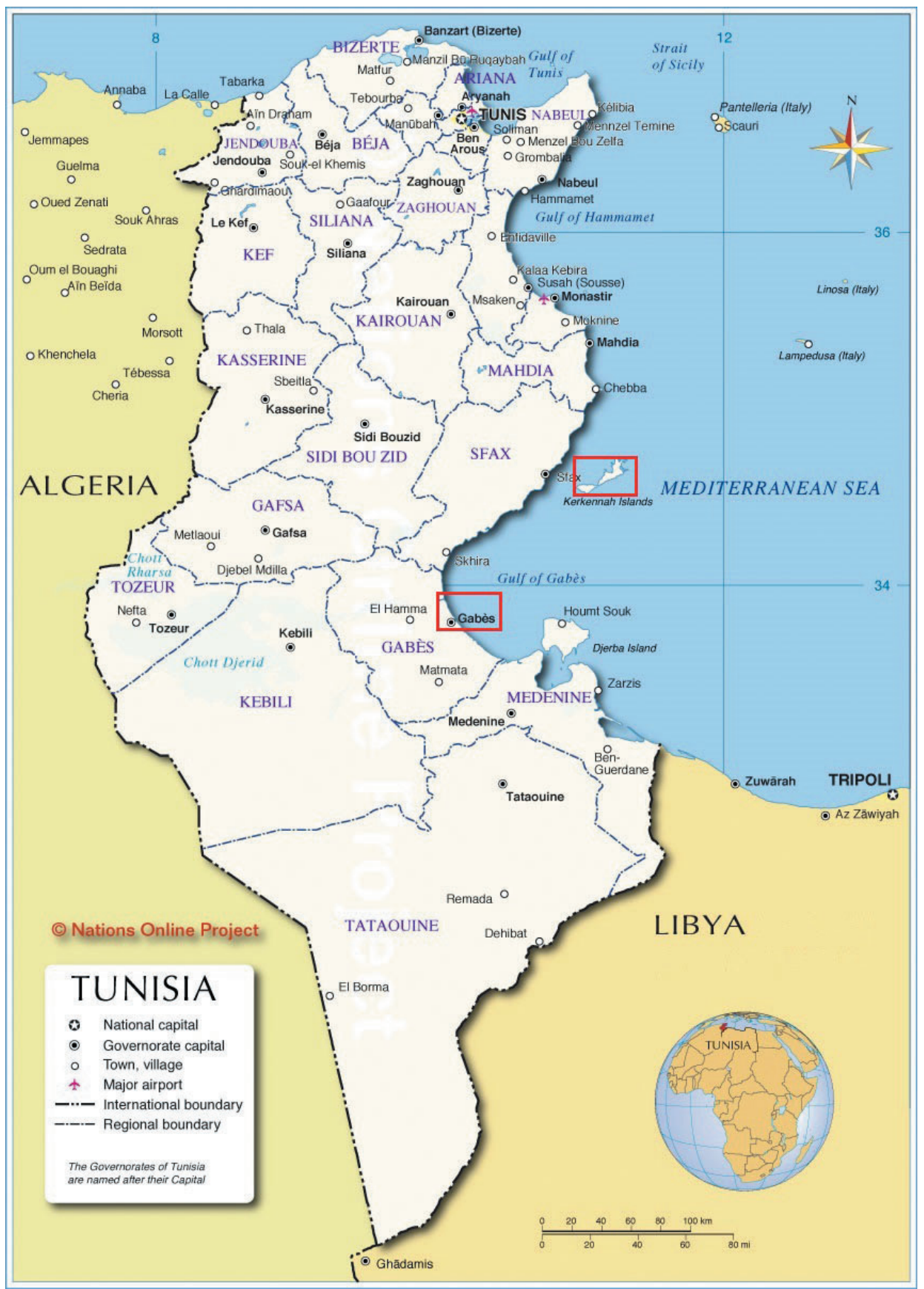

Fig. 1. Map of the Tunisia Governorates Source: www.nationsonline.org 




Fig. 2. Metropolisation in the 1999-2011 SDAT Master Plan

Source: Republic of Tunisia, Ministry of Environment and Spatial Planning, 1996. 
The third master plan stood out radically against the previous ones. It assumed that coastal regions are more ready for globalization than the interior regions which are considered brittle (MEAT 1996, 1997). The tradition of knowhow inherited from century to century, like textiles in the Sahel and the manufacturing industries in Sfax, explains this vision of planning (Neifar 2004). Nevertheless, this master plan emphasized the crisis of interior regions, especially their marginalization, unemployment, and lack of opportunities, in addition to unfavourable climatic and soil conditions.

\section{Failure of the regional economic planning}

During four decades and parallel with different master plans many actions and projects were undertaken by the Government to reduce the development gap between the North, South, East and the West, especially during the cooperative period (1961-1969) (Ruf 1975). Since 1960 the State has tried to reduce the inherited imbalance between the Tunis and other regions, and between coastal regions and mainland. The Tunisian government wanted to stimulate dynamics in the interior regions and in the South, therefore, it created many poles of development. The State formed regionalised poles in different regions of the country. Thus, since the 1960s, it has implanted industrial units, such as the steel complex of Menzel Bourguiba (North-East), the paper pulp plant of Kasserine (Centre-West), the textile complex of Ksar Hellal (Center-East), the sugar factory of Beja (North-West), cement plants in several cities, the acquisition of NPK in Sfax by the State(Centre-East), and construction of the commercial port and Maghrebi chemical industry in Gabes (South-East) between 1969 and the early 1980s. On the other hand, in 1959, the government commenced to develop tourism sector in the coastal areas of Hammamet, Nabeul, Sousse, Monastir, Djerba, and Zarzis.

This policy resulted in that the industry and tourism have been privileged by the State at the expense of the agricultural sector which remained on the side-lines of investments. Indeed, agriculture was supposed to produce products at affordable prices for the working class and for the urban population. Nevertheless, the poles of development launched by the State have become the only growth poles. The glaring imbalance remained (Dhaher 2010) between the coast and the interior regions, but also between the cities and the rural areas.

The various International Monetary Fund (IMF) programs (Structural Adjustment Programme SAP 1986 and Competitiveness Programme in 1995), the development aids and loans imposed to the Government a severe disengagement from economic investments. The State became only responsible for basic infrastructure such as roads, hospitals, education, etc. Coastal and tourist areas have benefited from most infrastructures that came from public and private investments at the expense of inland areas and the rural areas. Apart from planning problems, the policy of compulsory and free education for all citizens led by the government after the independence has resulted in an unprecedented number of highly skilled unemployed individuals. State disengagement from the economic investment has increased the problem of youth unemployment in the country.

\section{Diagnosis of the crisis}

Unemployment became structural. It is associated with the demographic composition, which means that the number of unemployed youth in working age remains important. Unemployment is also directly linked to economic growth, which was around $5 \%$ before 
the revolution. In 2010, the unemployment rate reached $14 \%$ (official statistics) ${ }^{2}$, while according to the informal statistics $25 \%$ of people in working age were unemployed. In 2013, this percentage reached $16 \%$. The corruption cases in the presidential family, some of them disclosed in the internet and in social networks, have aroused a sense of injustice and revolt among the citizens. The crisis in Tunisia was exacerbated by choking and locking the political life ${ }^{3}$, lack of respect for human rights and for human dignity. This situation has lasted for more than fifty years.

\section{Self-help: a response to the crisis}

With the disengagement of the State people from certain localities chose migration or immigration. Others went to work and sought solutions in their own place highlighting expertise and knowhow rooted in their culture. Some economists evoked endogenous development (Courlet and Pecqueur 1996) while scientists in regional studies evoked the development "from below" (Stöhr 1981). The localities that demonstrated this development were even classified as a development model, called "localized productive system" LPS (Courlet and Pecqueur 1996). Gagnon (2002) and Theys (2002), identified this action as Sustainable Territorial Development (STD). For us, while accepting the terms already presented, we believe it would be appropriate to qualify the action of these localities, as "Self-Help". It is the development by using the full potential of cultural, natural, and economic resources of a locality in order to overcome difficulties and to establish socio-economic prosperity.

Several regions in the coastal cities of Tunisia (Northeast, Centre-East and Southeast) invested in industrial sectors like textile in Sahel, manufacturing industries in Sfax, and tourism in Sousse, Hammamet, and Djerba. They realized early, that the State, very centralised as it was, would not come to their rescue. They have used their knowhow and their work to defy the fate. But some other people chose to migrate to Tunis as it was the case of the inhabitants of Ouedref and Métouia in the governorate of Gabes. Inhabitants of other localities headed for Europe, like those of Ghomrassen in the Governorate of Tataouine (South west), of Msaken (governorate of Sousse), and of Mahares (Governorate of Sfax), etc. (Neifar 2004)

The study of Ghannouchis and Kerkennians was motivated by the fact that despite the hostility of the natural environment, and unlike other communities, the remaining inhabitants in these two areas have adapted the environment in which they lived to their needs. They did not hesitate to move for one or many days to operate in other areas sometimes hundreds of kilometers from their home.

\footnotetext{
2 To meet the requirements of international agencies and funds and to give a rather positive picture of economic growth in the country, the regime of President Ben Ali has not hesitated to manipulate the methods of calculating unemployment rate in the countrie.

3 Leaders of political parties are persecuted by the regime, everywhere, in Tunisia or in foreign countries. In fact, only the opposition parties, close to the regime are authorized to hold meetings and activities. Like the economy, politics becomes in Tunisia a family affair.
} 


\section{Ghannouch, the agriculture or the determination of Man towards nature:}

Ghannouch with 22,681 inhabitants in $2004^{4}$ (National Institute of Statistics, INS) is a coastal delegation which belongs to the governorate of Gabes. This delegation is an ancient oasis. The urban sprawl has consumed over the years the old oasis located north of the delegation and separated the city from the sea (Neifar 2004).

A) The narrowness of the agricultural horizon

The rapid urbanization and degradation of the ancient oasis have reduced the amount of exploitable farmland in Ghannouch. On the other hand, the commercial port and the Maghrebi chemical industry in Gabes limit any extension to the south, while the Mediterranean Sea to the east, the national road and the city of Metouia to the west, and a series of lagoons and wet areas to the north. Despite this, Ghannouchis, known as strenuous farmers, have used the wet areas in order to gain new lands for their agriculture (Neifar 2004).

B) The land reclamation to the detriment of wetland areas

This strategy was developed by Ghannouchis since 1990 (Neifar 2004, 2011). It covered the wet areas owned by the State, located north of the delegation of Ghannouch. The land reclamation and improvement consists in removing halophytic vegetation ${ }^{5}$, tilling the land with animals to prevent soil compaction and mixing earth with the beach sand and animal manure.

Reclaimed land extends along the coast to more than five kilometers from the centre of Ghannouch (Neifar 2004, 2011). The newly reclaimed plots are usually planted with

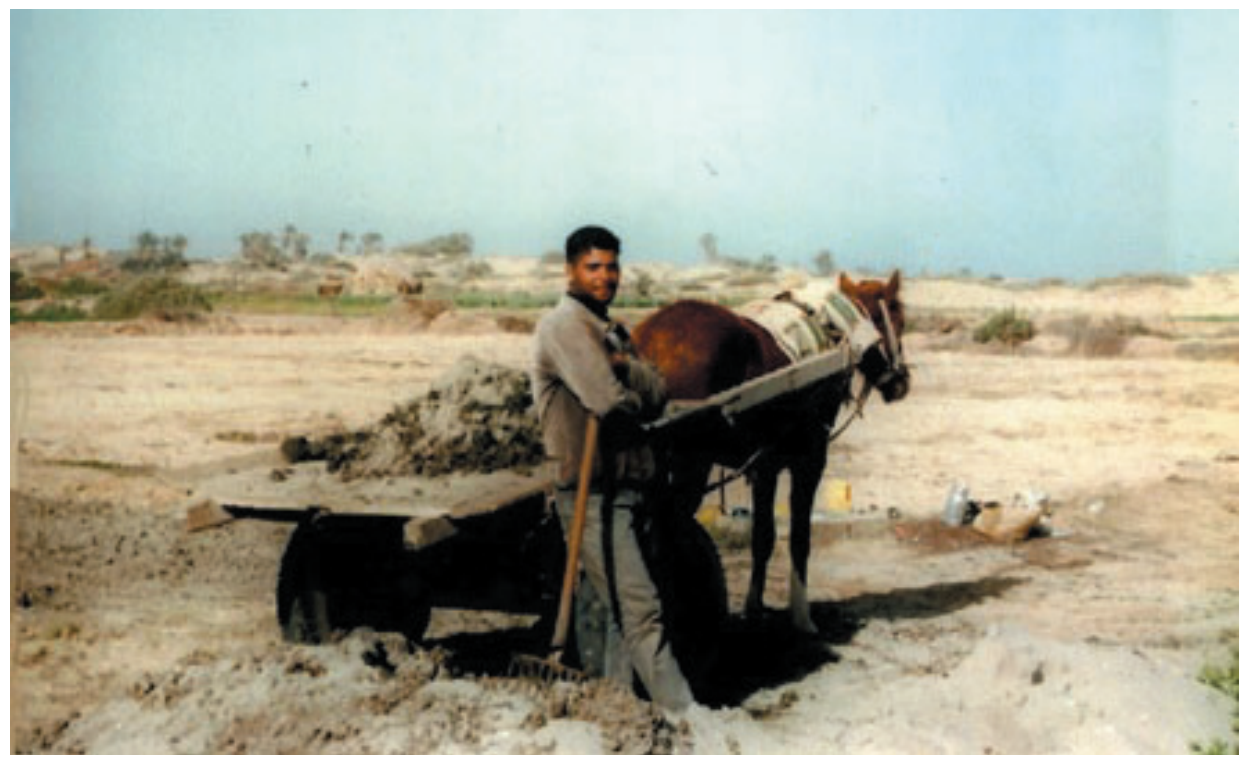

Photo 1. Traditional method of land reclamation used by Ghannouchis (by the author, 2002)

${ }^{4}$ The population census of 2004 is still now the last official census while, the census of 2014 is not yet published.

5 Plants tolerating salinity. 


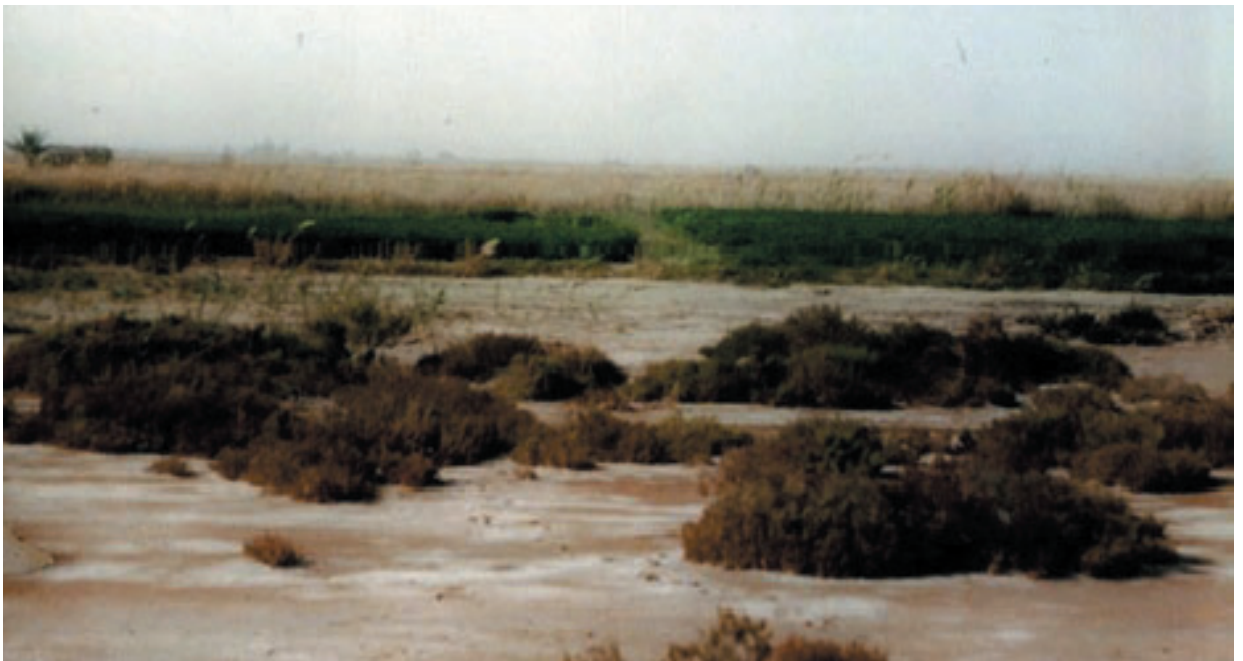

Photo 2. Wet and reclaimed areas in Ghannouch in March 2002 (by the author)

onions, carrots, alfalfa. Though this is public land, many Ghannouchis have used and worked this land illegally for a few years before selling the right of use and operating to another Ghannouchi.

C) Appropriation of lands

Ghannouchis have developed this technique since the 1990s (Neifar 2004) in various localities and in neighbouring localities in the governorate of Gabes. They reach up to forty kilometers from the city of Skhira in the south of governorate of Sfax. In recent years the trend is to make profit with land reclamation in the north of Ghannouch, and after many years the income is used to buy land with a property title in other localities. Indeed, Ghannouchis reclaim land in wet areas and operate it for a few years before selling the right to use the land to another farmer.

\section{Fishing or the struggle for survival of Kerkennians}

A) The narrowness of the marine and terrestrial horizon on the Island

Kerkennah is an archipelago consisting of two main islands with an area of $160 \mathrm{~km}^{2}$. The archipelago is commonly called the Kerkennah islands. The population of the islands has stagnated over the last fifty years at around 14,400 people (INS 2004). For decades the islanders have migrated to the Mainland, particularly to Sfax and Tunis. Those Kerkennians who do not migrate live mainly of fishing. Despite a certain slowdown the coastal fishery continues to be the leading employment sector on the island. In Kerkennah, people from villages like Mellita, El Attaya, and El Kraten devote themselves entirely to this sector. In 2000, according to the official statistics of the Tunisian National Board of Fisheries ONP (Neifar 2004), there were 4460 fishermen in Kerkennah islands, i.e. nearly $30 \%$ of their total population. Tourism, which is a very marginal activity, involved only 240 people in 1999 (Neifar 2004), while agriculture is almost absent due to the lack of arable land. 
B) The mobility for following fishing seasons

Kerkennians cannot rely on their nearest sea waters, i.e. the shallow sea which is not rich in fish, so they move away to other marine areas looking for shrimp. Each year in April with the end of the octopus season ${ }^{6}$ the fishermen from Kerkennah concentrate their efforts on shrimp fishing on the coast of their islands. They move successively to the south, in the Gulf of Gabes, in front of the coast of Skhira, and then those of the Gabes region finally arrive off the island of Djerba, especially in "Esseguia"7 (Fig. 3), which is approximately 120 kilometers from their shores.

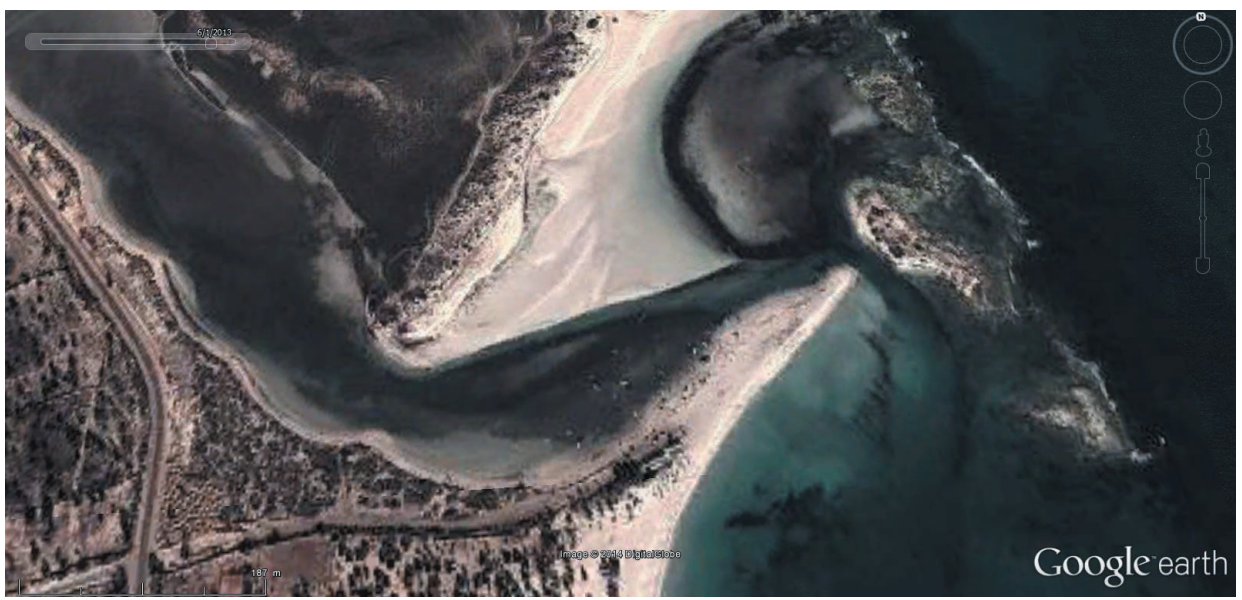

Fig. 3. "Esseguia" is formed by two natural shelters dominated by an advancing sandy spit that divides the two shelters into two opposite points of embarkation (Google Earth 2013)

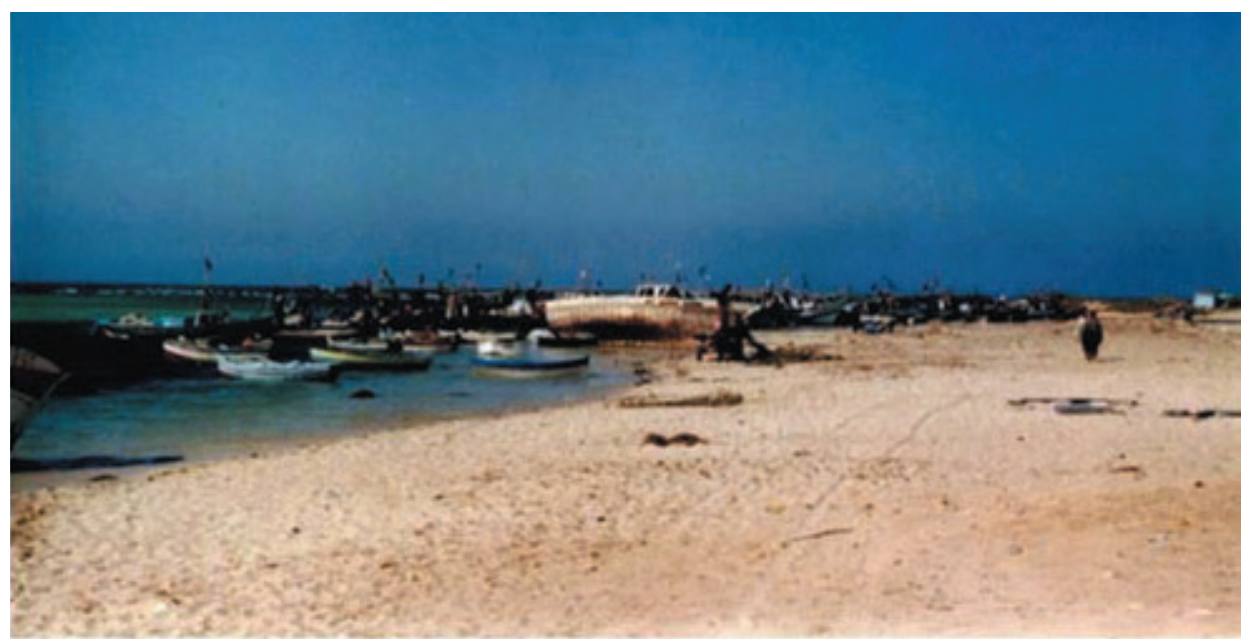

Photo 3. Djerba "Esseguia"in May 2002 (by the author)

6 The octopus fishing begins in August of each year and ends in April.

7 Esseguia is a natural harbour, on the eastern coast of Djerba in front of huts that became later the Club Med, launched by its owner Gilbert Trigano, in 1954, (Neifar 2005). 
We obtained this confirmation in May 2002 during the shrimp fishery season on the Djerba island. At that time, we counted 26 boats that belonged to Kerkennians, of a total of 46 present to this day in "Esseguia" (Photo 3).

In March 2003 we returned to "Esseguia" on Djerba island and we only found three Djerbian fishers on-site who prepare their boats for the next season and we didn't find any fishermen from Kerkennah. The absence of Kerkennian fishermen is explained by the fact that the season normally starts in May.

\section{New technologies for proving the local dynamics}

\section{Google Earth: a tool that reflects the liveliness of Ghannouchis}

The informal nature of this agriculture does not allow obtaining official statistics concerning the surface area of the lands reclaimed. Neifar (2004) said that around 600 ha were reclaimed by Ghannouchis. Today, with the free access to satellite images, we used Google Earth Pro to measure the areas acquired over approximately two decades by Ghannouchi at the expense of the lagoon areas and the coastal dunes (Fig. 4).The measurements carried out have enabled us to find that currently there are approximately 1,116 ha in this area that officially belongs to the State; however, this land is unofficially under the control of farmers from Ghannouch.



Fig. 4. Measuring the areas acquired unofficially by farmers from Ghannouch, Google Earth Pro

After the revolution, the as a result of pressure put by people of Ghannouch on the transitional government to hire the unemployed youth in the commercial port and the Maghrebi chemical industry in Gabes hundreds of people were employed. Consequently, some reclaimed land areas were abandoned by the unemployed youth for the benefit of a job in the chemical group. Qualitative fieldwork conducted in April 2013 showed that young people preferred to work in a stable structure like the chemical group because it was better than working on land owned by the State, (public land) that might be taken by the authorities any time. After the revolution, in 2011, the unemployment rate in Ghan- 
nouche was the lowest in the whole Governorate of Gabes with only 5.4\% against 18.1\% for the entire Governorate ${ }^{8}$.

The comparison of Google Earth images using the application "historical imagery", between January 2004 (Fig. 5) and March 2013 (Fig. 6) shows the land abandoned which was already reclaimed by Ghannouchis and a decline in planting surfaces in the same area. This is related to the jobs found in the chemical group, but also to the soil degradation after the land reclamation. Nevertheless, we did not find any statistics on land abandonment by the youth who found employment in the chemical group of Gabes.

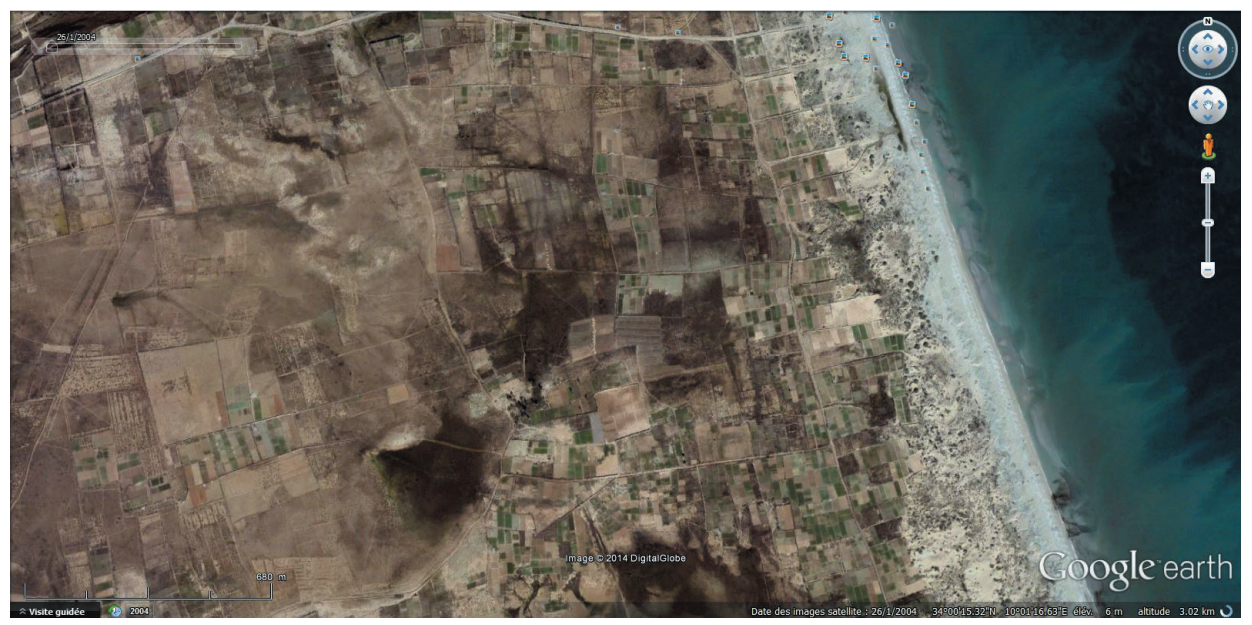

Fig. 5. Google Earth 2004

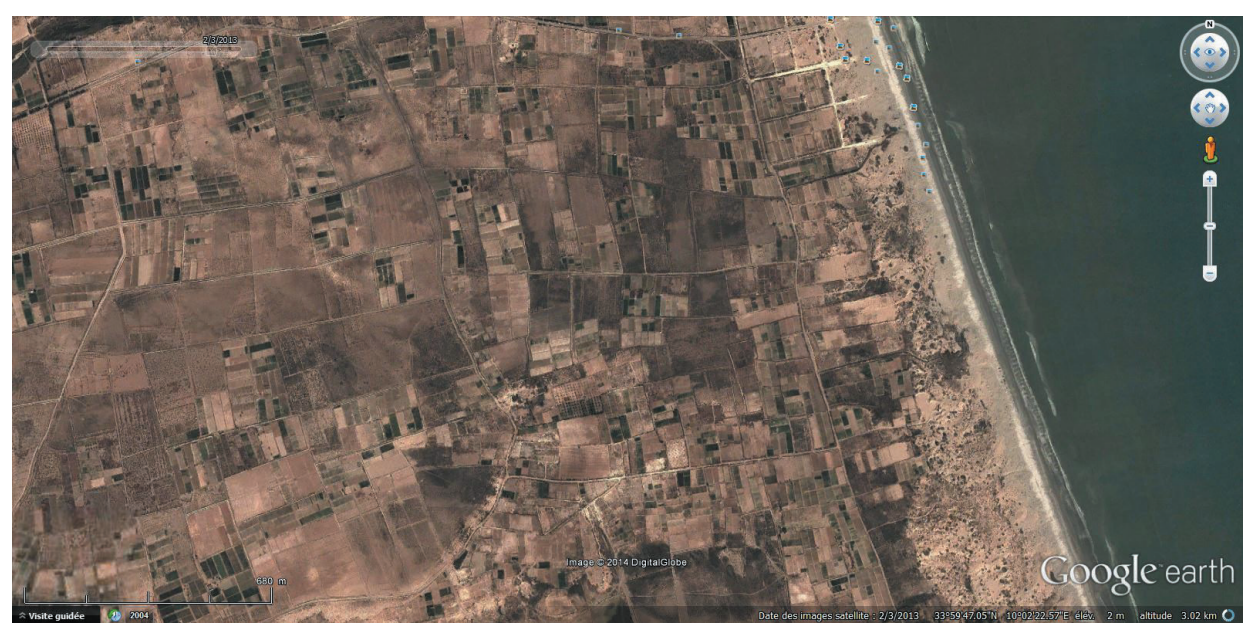

Fig. 6. A decline of planted surfaces in 2013 compared to 2004, observed from Google Earth images history. Google Earth 2013

${ }^{8}$ Governorate of Gabes in numbers, ODS 2011. 


\section{Google Earth: the mobility of Kerkennians}

We noticed the mobility of fishermen, Kerkennians, when we conducted fieldwork throughout the Gulf of Gabes. To verify and confirm this fact we used Google Earth and its extension, "historical imagery", to review a succession of satellite images of Esseguia in Djerba during the shrimp season between April and June. Available images that coincide with the period of the shrimp campaign could be found between May 2008 and May 2010.

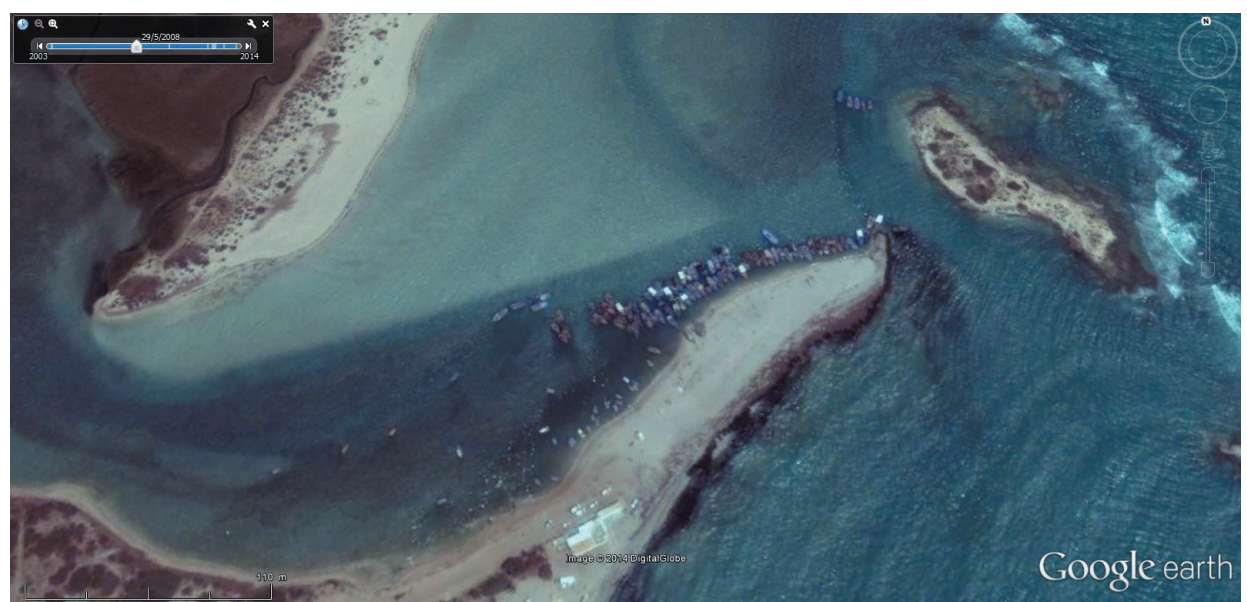

Fig. 7. Google Earth May 2008

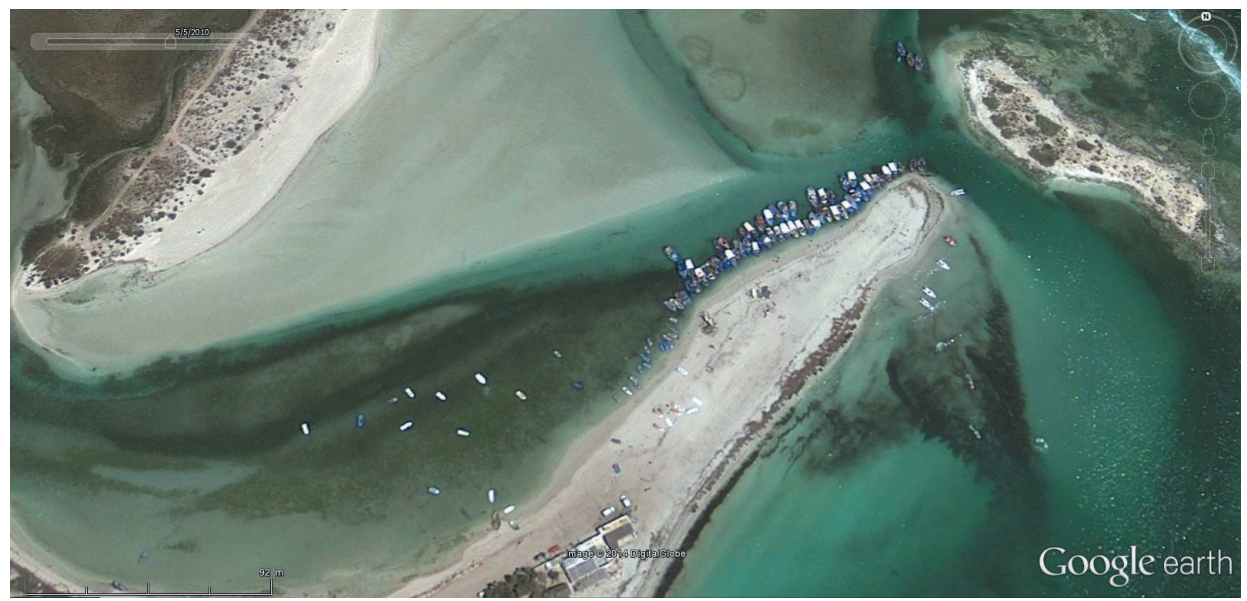

Fig. 8. Google Earth May 2010 
The analysis of Esseguia's images shows and confirms the continuity of the presence of the Kerkennian fishers during the shrimp campaign. This observation was already checked during field surveys conducted between 2002 and 2013. Nevertheless, the situation has changed after the revolution of 14 January 2011.

After the revolution, Kerkennians continue to follow fishing campaigns and especially shrimps in the Gulf of Gabes. All of a sudden, during the 2013 campaign, Kerkennian fishermen were prevented from fishing for shrimp around from Djerba coast by fishermen from Djerba. Indeed, in May 2013, nearly 300 boats were returned from Djerba (see Tunisian newspaper "Le Temps" May 15, 2013). Until June 2013, Kerkennian fishermen had not reach an agreement with the authorities to cope with their fishing ban imposed by the Djerbian fishermen.

With a limited continental horizon and a maritime horizon increasingly restricted by pollution and by opposition from fishermen from other regions, Kerkennah remains a marginalized archipelago. Nevertheless, Kerkennians who wish to stay on the island continue to fish. Recent statistics ${ }^{9}$ on the number of fishermen in Kerkennah show 6915 fishermen in 2011 against the total population of 14,497, or $47 \%$ of the total population of Kerkennah. The statistics show also that Kerkennians make $49 \%$ of the total number of fishermen in the governorate of Sfax.

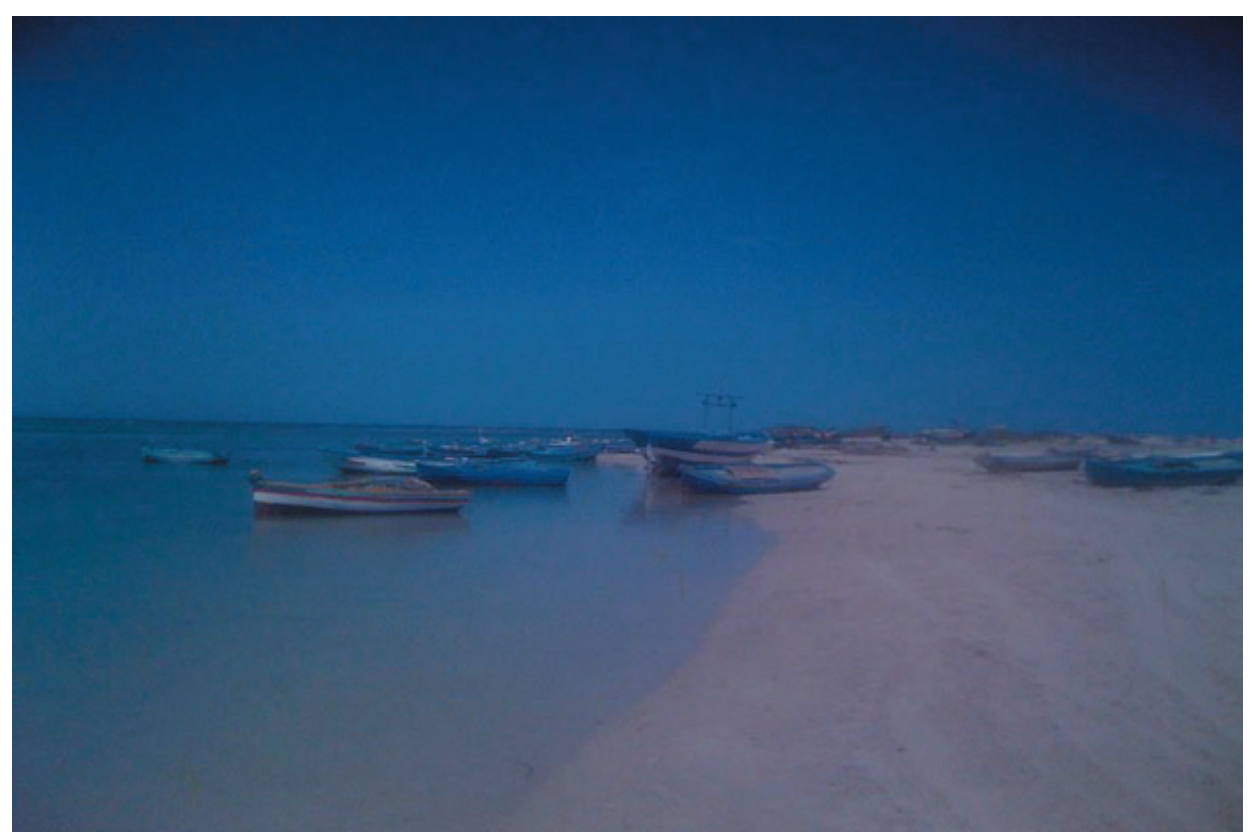

Photo 4. Absence of Kerkennians in "Esseguia" on the Djerba Island in May 2013 (by the author)

\footnotetext{
9 Estimation of the General Commission for Regional Development (CGDR) 2012.
} 


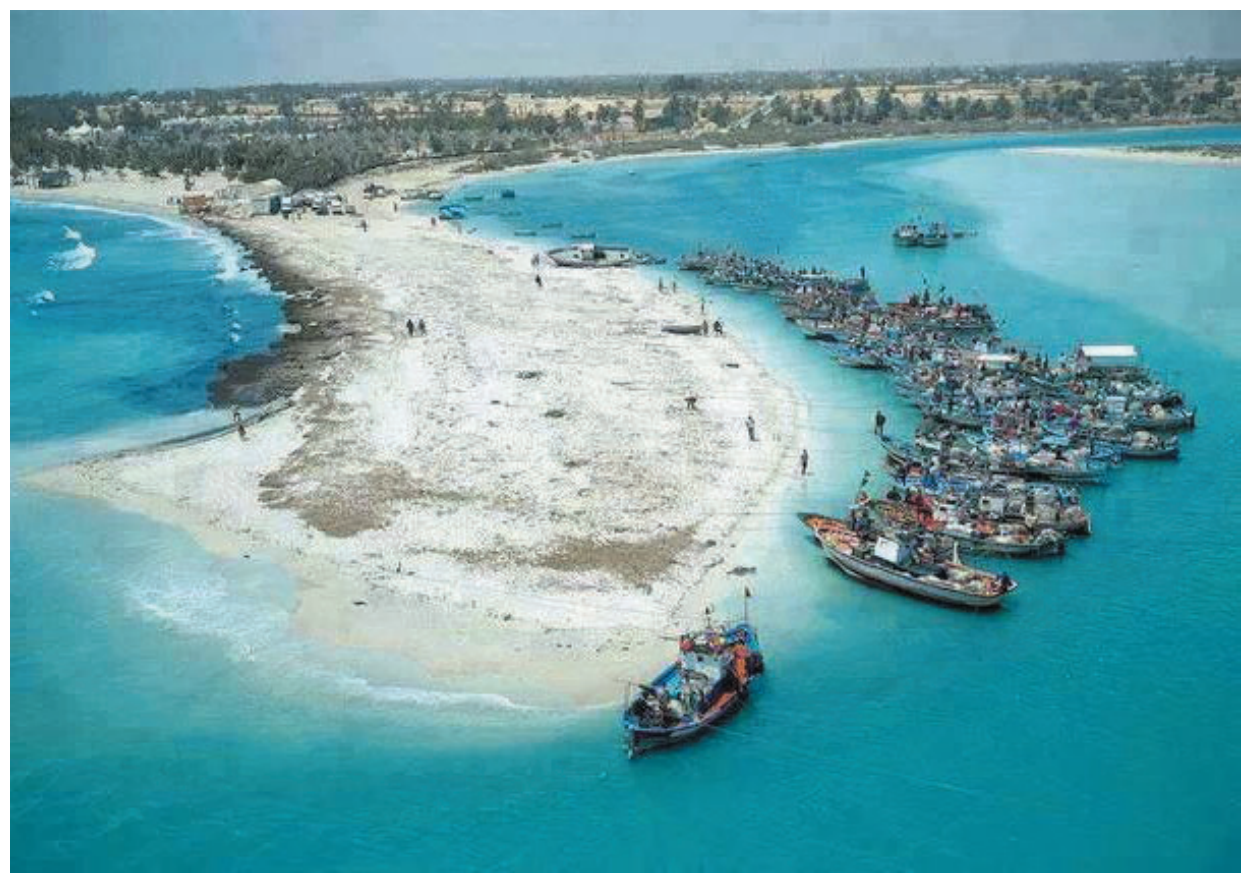

Photo 5. Kerkennians in Djerba "Esseguia" during fishing campaigns. Anonymous photo from the Internet

\section{Conclusion and discussion}

In terms of scientific input this study shows the dynamics of local communities in Tunisia. Indeed, despite the difficult and hazardous natural environment, lack of interest and support on the part of State or regional authorities, these communities in Ghannouch and on Kerkennah islands are often forced to develop their own development strategies. Their dynamics are drawn from their cultures and from their knowhow. They use all their potentials to adapt their environment to their need. The situation could change in the coming years and the role of the State and local authorities may become closer to the people's aspirations. Indeed, the members of the Constituent Assembly have finished writing the country's new constitution. The new constitution gives priority to decentralization. Article 128 refers to a new division of the territory based on municipalities, regions, and departments. As it is mentioned in the new constitution, the financial and decision-making autonomy will bring benefit to marginalized areas of the country. Indeed, spaces marginalized for decades will no longer wait for a central decision from the capital. The locally elected officials will be able to effectively decide about the future of their territories and contribute to their development. Indeed, the election of all members of various local councils can render the decision-making process loyal to local spaces and not to the central government. This could enhance the efficiency of the development of marginalized areas and spaces situated far from the capital Tunis. Nevertheless, planning must be coordinated and must take into account the realities, dynamics and local aspirations.

On the other hand, this study has been supported by one tool that is accessible for all, namely Google Earth, in its free and paid version. It confirms the findings made during 
the investigation work and during the years of observation and confirms the socio-spatial changes in the Gulf of Gabes. With Google Earth Pro we measured the areas acquired by Ghannouchis at the expense of the lagoon areas and at the expense of coastal dunes. We have found that these areas currently amount to 1,116 hectares. The ownership of this land lies with the State. The surface area of new extensions of 1,116 ha is largely outside the perimeter of the delegation which is about $1900 \mathrm{ha}^{10}$. It demonstrates the importance of these extensions which represent $57 \%$ of the total area of Ghannouche. Yet, in terms of sustainable development these extensions show an intensification of agriculture which leads to the deterioration of the land quality and land abandonment (Neifar 2004).

The "historical imagery" tool of Google Earth seems to be helpful for the geographers, especially in respect of the diachronic images. Indeed, any changes may be quickly observed in the field and many geographic arguments could easily be confirmed with the visualization of different images from Google Images History. Nevertheless, the resolution and image quality available, including historical images, can be a barrier to a more specific geographical research. This adds to the inadequacy of available periods of scientific studies and work goals. For example, for our study on the mobility of the Kerkennian fishermen in Esseguia Djerba we have found that the last image of Google Earth was of May 2010 and no more images for the month of May were available. Especially, as it is during this month that Kerkennian fishermen are fishing for shrimp in Djerba Esseguia.

Eventually, the case of Kerkennah and Ghannouch in Tunisia are not isolated in the Maghreb regions and in the south of the Mediterranean Sea. Actually, several areas are known for their strong personalities and their populations do not hesitate to undertake actions, to make changes on the territory and to challenge hazardous natural environment conditions. They are all the time looking for new spaces that could satisfy their desires. For some traders and gifted artisans this was the case of Mozabites in Algeria and Afassians in Morocco. In Senegal, the Diola farmers in Casamance produce a value in the rice paddies similar to the Chinese rural areas. Hence, it is important to study these different areas in order to make a comparison and address the key similarities and differences. This would allow the elected decision-makers to better understand the potential of each region, so that all interventions, including international organizations, can best meet local aspirations.

\section{References}

Courlet C., Pecqueur B., 1996, Districts industriels, systèmes productifs localisés et développement [in:] Courlet C., Abdelmalki L. (eds.), Les nouvelles logiques de développement, Editions I'Harmattan, Paris, pp. 91-102.

Daoud A., 2011, La révolution tunisienne de janvier 2011: une lecture par les déséquilibres du territoire, EchoGéo [En ligne], Sur le Vif, mis en ligne le 23 septembre 2011, http://echogeo.revues. org/12612.

Dhaher N., 2010, L'aménagement du territoire tunisien: 50 ans de politiques à l'épreuve de la mondialisation, EchoGéo[En ligne], numéro 13|2010, mis en ligne le 20 septembre 2010, http:// echogeo.revues.org/12055

\footnotetext{
${ }^{10}$ Office of development of the South ODS 2011.
} 
Dirasset-Groupe Huit-IGIP, 1997, Schéma Directeur d'Aménagement du Territoire National, résumé recommandations et conclusions. 23 pages.

Direction Générale de I'Aménagement du Territoire (D.G.A.T) Tunisie, 1985, Schéma National et Schéma régionaux d'Aménagement du Territoire et Atlas.

Gagnon C., 2002, Modèle de suivi des incidences sociales, évaluation environnementale et développement régional viable, Rapport de recherche, Chicoutimi, GRIR éditeur / Université du Québec à Chicoutimi, 163 p. Disponible en ligne: www.uqac.ca/msiaa

http://books.openedition.org/iremam/100

Ministère de l'Environnement et de l'Aménagement du Territoire (M.E.A.T) Tunisie, 1996 et 1997, Schéma National d'Aménagement du Territoire. Rapports de première et deuxième phase.

Neifar B., 2004, Littoralisation et aménagement de l'espace : les modèles socio-spatiaux du Golfe de Gabès (Tunisie), Thèse de doctorat de l'université d'Aix-Marseille I.

Neifar B., 2005, Jerba: les mutations récentes d'un système insulaire, Revue Mappemonde, 77.

Neifar B., 2011, Vers une nouvelle Géographie du Golfe de Gabès en Tunisie: étude géographique d'un espace méditerranéen, Editions Universitaires européennes.

Ruf K. W., 1975, Le socialisme tunisien: conséquences d'une expérience avortée, [in:] Introduction à I'Afrique du Nord contemporaine, Nouvelle édition. DIR. CRESM, Institut de recherches et d'études sur le monde arabe et musulman, Aix en Provence, pp. 399-411.

Stöhr W. B., Taylor F., 1981, Development from above or below, John Wiley, Toronto.

Theys J., 2002, L'approche territoriale du développement durable, condition d'une prise en compte de sa dimension sociale. Développement Durable and Territoires, Disponible en ligne http:// www.revue-ddt.org/dossier001/D001_A05.htm, DOI : 10.4000/developpementdurable.1475

\section{Sources:}

Governorate of Gabes in Numbers, Office of development of the South ODS 2011.

Governorate of Gabes in Numbers, Office of development of the South ODS 2012.

Governorate of Sfax in Numbers, General Commission for Regional Development CGDR 2012.

I.N.S., 1994, General Census of Population and Housing.

I.N.S., 2004, General Census of Population and Housing. 